\title{
CRITICISM CITY SPACE ARCHITECTURE: A CASE STUDY FISH LANDING STATION OF PAOTERE, MAKASSAR CITY
}

\author{
Sriany Ersina \\ Prodi Teknik Arsitektur \\ Fakultas Sains dan Teknologi UIN Alauddin Makassar \\ J1. Sultan Alauddin No. 63, Kabupaten Gowa, Sulawesi Selatan. 92113 \\ E-mail: sriany.ersina@uin-alauddin.ac.id
}

\begin{abstract}
Makassar City as the capital city of South Sulawesi province has the potential and opportunity to develop its fishery industry to become the center of the largest fishery industry in Eastern Indonesia. One of the fishing ports in Makassar City is a Paotere fish landing station. The Paotere fish landing station is in the northern part of Makassar City and is located on J1. Sabutung I No.3, Kelurahan Gusung, Ujung Tanah District, Makassar City and is the center of a fishing port that has many activities and is related to fish auction needs, such as auction, fish unloading, and ship supplies. This study aims to identify fish landing base areas in the city of Makassar, and in general, can be a reference for the Makassar City Government in determining development strategies in planning and designing fish landing bases in Makassar and Sulawesi cities. This study is based on a rationalistic descriptive paradigm with a normative architectural criticism approach which refers to the urban design elements of Hamid Shirvani's theory (grand concept / grand theory). The results of this study indicate the need for planning and redesigning the Paotere fish landing station area in Makassar city.
\end{abstract}

Keywords: elements of urban design, port, fish landing station

\section{INTRODUCTION}

I ndonesia is an archipelago/maritime country consisting of approximately 17,500 islands with a sea area of 5.8 million $\mathrm{km}^{2}$, which is $75 \%$ of the total area of Indonesia. The oceans in Indonesia are famous for their rich species of marine flora and fauna. This has led to the growth of various marine-related activities including fisheries activities. Fishery activities have a very big role in improving the nutritional value of the community, increasing the standard of living for the population, especially fishing communities, and for the Indonesian economy. The condition of the Indonesian sea has a very large influence on increasing national income from exports and imports through fisheries activities. Judging from fishery production in Indonesia, based on the distribution of its territory, the island of Sulawesi in the region that has the largest marine fishery production in Indonesia. This shows that the fisheries sector is one of the main dimensional activities in Sulawesi Island, particularly Makassar city, South Sulawesi.

Makassar City as the capital city of South Sulawesi province has the potential and opportunity to develop its fishery industry to become the center of the largest fishery industry in Eastern Indonesia. Geographically, this is supported by the location of the city of Makassar, which is one of the largest cities and the gateway to the Eastern Region of 
Indonesia, and will automatically become the gateway for exports of trade products in general.

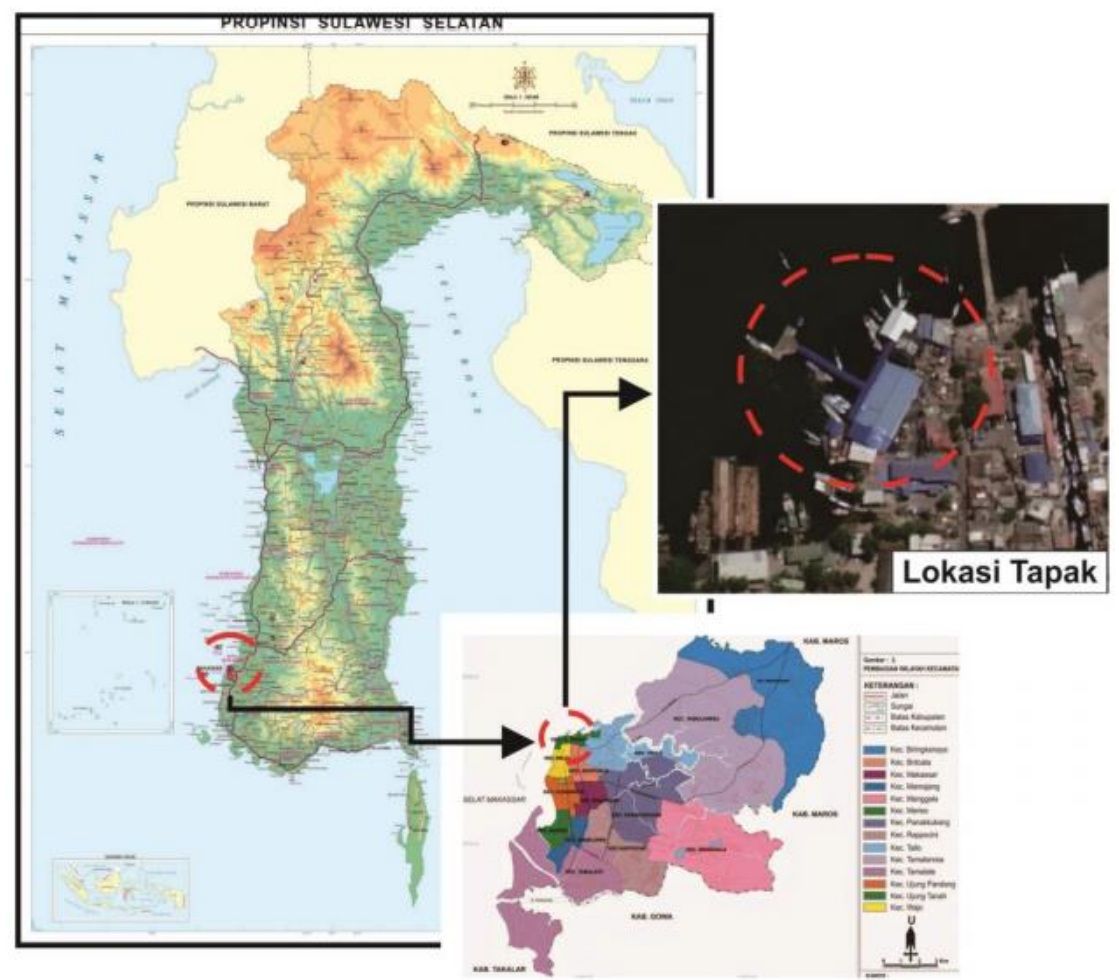

Figure 1. The location of the Paotere Fish Landing Station in Makassar City

(Source: Results of data processing, 2019)

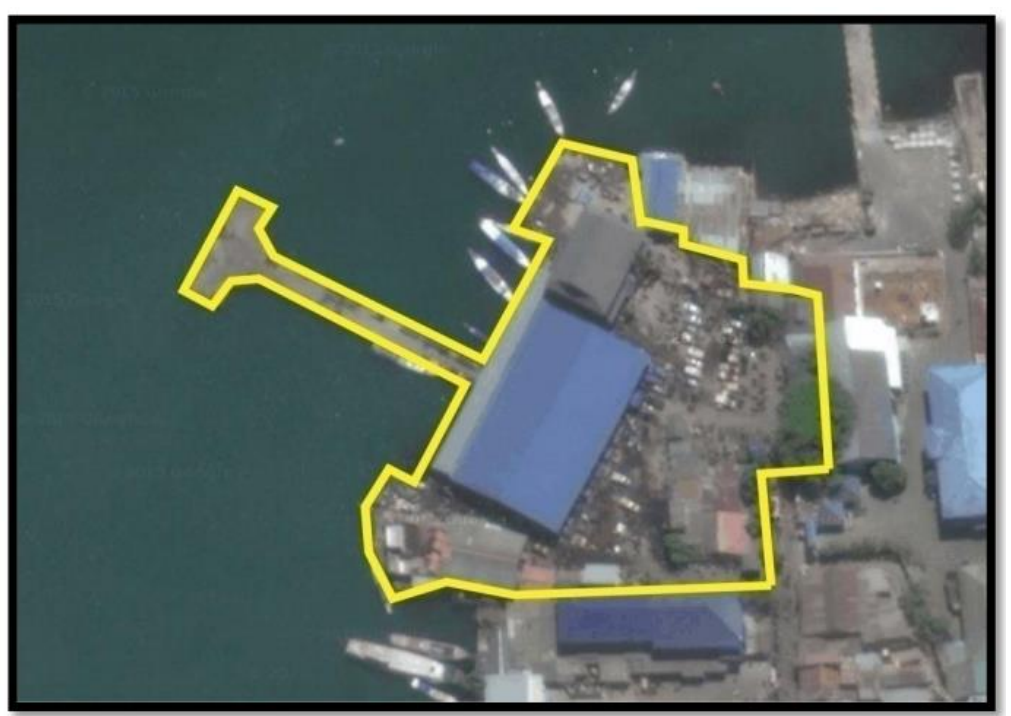

Figure 2. Paotere Fish Landing Station of Makassar (Source: UPTD Paotere Makassar, 2019)

Makassar City as a port city has a very potential marine area to be utilized. One of the fishing ports in Makassar City is a Paotere fish landing station. The Paotere fish landing station is in the northern part of Makassar City and is located on J1. Sabutung I No. 3, Kelurahan Gusung, Ujung Tanah Subdistrict, Makassar City and is a capture fishery center that has many activities related to fish auction needs, such as auction, fish unloading, and ship supplies. 
According to Roosita (2007), a fishing port is the center of the fisheries business system activity. The port is used as a berth for fishing vessels, equipped with safety facilities for shipping and other fishery support activities. Eight elements of urban design by Hamid Shirvani, namely: 1) Land Use; 2) Building Form and Massing; 3) Circulation and Parking; 4) Open Space;5) Pedestrian Ways; 6) Activity Support; 7) Signage; 8) Preservation and Conservation.

According to Triatmodjo (2010), ports can be divided into several types depending on the point of view, namely in terms of implementation, exploitation, functions in national and international trade, in terms of use, and geographical location. Fishery port according to the Regulation of the Minister of Marine Affairs and Fisheries of the Republic of Indonesia number Per.08/MEN/2012 concerning Fishery Ports is a place consisting of land and waters around it with certain boundaries as a place for government activities and fishery business system activities used as a vessel. leaning fisheries, anchoring, and/or loading and unloading 18 fish which are equipped with shipping safety facilities and fisheries support activities (www.djpt.kkp.go.id, accessed July 14, 2019).

The Paotere Fish Landing station is a well-known fish auction place, where not only ships from Makassar City market their catches but fishing boats from various regions and even other provinces also come to market their catch. In addition to fishery trading activities, supporting activities are also needed at the Paotere Fish Landing Base because it can support fisheries activities, especially fishermen in the area.

The Paotere Fish Landing station has several problems in the aspect of facilities and infrastructure where as operational support it is still incomplete and the condition of the building still does not meet the standard needs of a fish auction place, this is because the fishermen are still selling their catch on a dirty floor with tarpaulin and unavailability water to flush the floor even though the floor must always be clean so that there is no odor pollution in the air. In addition, there is also a problem with the sewerage of waste originating from the fish auction. Another problem encountered was the chaotic arrangement of the area and unclear circulation patterns between the entry and exit routes of vehicles resulting in crosses between two- and four-wheeled vehicles and pedestrians, plus the lack of awareness of local residents in an effort to maintain environmental cleanliness that resulted in garbage scattered everywhere. This has led to the notion that a fish auction place is identical with a dirty, dirty environment, and is always the cause of an unpleasant smell in the air. These problems greatly affect the environment and community activities in Makassar city.

This study aims to identify the fish landing area in the city of Makassar where the results of architectural criticism thinking of urban design elements refer to the theory (grand concept/grand theory) of Hamid Shirvani. In general, this study is expected to become a reference for the Makassar City Government in determining development strategies in planning and designing fish landing bases in Makassar and Sulawesi cities.

\section{METHOD}

In this study, the method used is the data collection method in the Normative Architectural Criticism method. The data taken includes data about the architectural design elements of the city which contains the concepts in the planning process for urban areas. For normative criticism, its specificity needs to be distinguished in the following methods:

1. Doctrine (a general norm, immeasurable statement of principle)

2. The system (a norm for the arrangement of interrelated elements for one purpose)

3. Type (a norm based on a generalized model for a specific building category) 
4. Size (a set of estimates capable of defining a building / urban area quantitatively)

In this study, the focus used is normative criticism that is doctrinal or not measurable. In this critical study, it is more to encourage things to appear easy and direct the assessment to be simpler in the midst of the complexity of urban space architecture. Regarding the truth in a single sphere and putting the blame on other principles that disagree, Putting the truth more to individual considerations, There is a tendency to view urban spatial architecture partially and not holistically, Allows the growth of thoughts with "absolute" truths and widens conflict at the level of deep thought in urban spatial architecture.

\section{RESULTS AND DISCUSSION}

The Paotere Fish Landing station is located in the Paotere Port area which functions as a center for the Paotere fish auction, a traditional port, and a fishing settlement. Around the site, there are several government buildings and there are many stalls/stalls on the shoulder of the road to the site. Geographically, the Paotere Fish Landing station is located between $119^{\circ} 24^{\prime} 30^{\prime \prime}$ East Longitude and $5^{\circ} 6^{\prime} 19^{\prime \prime}$ South Latitude in Gusung Village, Ujung Tanah District, Makassar City with an area of $7,225 \mathrm{~m}^{2}$ or $0.72 \mathrm{Ha}$. The boundaries and size of the Paotere Fish Landing station area are described in the following figure: (a) In the north, bordering the fish breeding place; (b) To the east, bordering the DirectorGeneral of Sea Transportation, Class 1 Navigation District of Makassar; (c) In the south, bordering PT. Fishery of Nusantara (Persero); (d) In the west, bordering the sea.



Figure 3. The existing condition of the Paotere Fish Landing Station in Makassar City (Source: Results of data processing, 2019)

Analysis of 8 elements of urban design by Hamid Shirvani, of the Paotere Fish Landing Station in Makassar City:

1. Land use is the arrangement of land use policies to determine the best option for allocating certain functions so that it can provide an overall picture of how areas in an area should function. The land use of the Paotere fish landing station has land use as a fishery landing site which has a complex function so that the building is not limited to 
one building. The different functions of the building make the site divided into several zones, namely, zones for basic, functional, and supporting facilities.

2. The building form and massing discusses how the shape and masses of buildings in an area can form an area and how the relationships between the masses (many buildings) contained in the area. The shape and structure of the building mass in the area are also determined by the height of the building, KLB, KDB, material, and color. 1) The height and shape of the buildings around the area have traditional and minimalist architectural styles. The average building height is about $\pm 4-10 \mathrm{~m} ; 2$ ) Building floor coefficient (KLB): Based on the IMB, the height at the landing point of the Paotere fish consists of two floors of the building; 3) Basic building coefficient (KDB) Area of 7,225 ha with built and not built coefficient is a) Built: $4,477 \mathrm{~m}^{2}$; b) Unbuilt: 2,748 m; 4) Material and color: All buildings in the area use brick material, floors use tiles and roofs use tiles. The color is dominated by blue, this can be seen in the color of the walls and roofs of the regional buildings. The concept of building mass planning patterns is applied to provide convenience and comfort in the area of the paotere fish landing base as well as additional facilities in accordance with the functions and needs of the area.

3. Circulation of achievements at the Paotere Fish Landing station can be accessed from Jl. Yos Sudarso which is a two-way street then goes into the Paotere area, namely Kaptan Harun street to the site which is located on Sabutung street 1. The distance from the main road to the site location is $716.4 \mathrm{~m}$, while the distance from the center of Makassar City is $\pm 5 \mathrm{~km}$ ( \pm 30 minutes). This area is close to the main base of the Indonesian Navy and the Ministry of Transportation, Polytechnic Science of Shipping. Vehicle circulation in the site is the circulation through which all activities in the area, namely the circulation of humans and vehicles. In the Paotere Fish Landing station area, there are several parking points for motorized vehicles. The area of the parking lot currently being built is $400 \mathrm{~m}^{2}$. Vehicles that use parking services for four-wheeled vehicles are fish transporting cars which reach 21 units/day and visitor cars reaching 10 units/day, while motorbikes are divided into two, namely visitor motorbikes and fish transporting motorbikes which reach 536 units/day. This is based on the author's survey of the PPI Paotere area. For the classification of car park users, it is dominated by fish carriers and cars, while visitors are still minimal.

4. Open space in the area of paotere fish landing base in the form of a yard or empty land used for parking vehicles and roads. The condition of open space in the Paotere Fish Landing station area is still minimal, where there is no open space that can be enjoyed either inside the site or around the site.

5. Pedestrian is one of the connecting elements which is a common city space that allows city residents to interact without having to compete with vehicles. The condition of the site does not have a special pedestrian area, visitors only use a vehicle road on a site that has experienced paving block pavement, therefore it is necessary to plan a pedestrian path in the area "Paotere Fish Landing station in Makassar City" which connects the spaces on the site, making it easier for visitors to move, especially in activities using special pedestrian ways.

6. Signage is a very important element in an area or site, this is because the signage has a function to direct and introduce a place to visitors in the area as well as markers that are on the site of the Paotere Fish Landing station area in Makassar City. The condition of signage in the area: There are several signs/billboards in the Paotere Fish Landing station area, among others, are as follows: 1) There are three billboards that are 
prohibited; 2) There are six building location signages, five of which are no longer conducive; 3) Only one traffic sign is available at the site. Signage on the Paotere fish landing station area is divided into namely: Area signage Fish landing station consist of a gate marking the entry and exit of the site, the area's main sculpture, and the area name sculpture. Area signage in the paotere fish landing area consists of motorbike parking signage, car parking markers, prohibited motorbike entry markers, prohibited entry markers, prohibited entry markers, signs prohibited from storing corks/crates, and signage in the area only renew to make it look more interesting.

7. Activity Support in the Paotere Fish Landing station area should have a component that has a selling value apart from the main function of the area, namely as a tourist and recreation place so that the area can still provide added value and help activities that occur in the area.

8. Preservation and conservation in the Paotere Fish Landing station area is an effort to protect plants around the coast and harbor from corrosion, as well as to maintain existing buildings in the area that have historical value.

\section{CONCLUSION}

From the description above, it can be concluded that the Paotere Fish Landing Station area in Makassar city as a whole does not meet the area design standards of Hamid Shirvani ( 8 elements of urban design), from the analysis of the grand concept/theory of city spaces architecture, it is reasonable for the Fish Landing station in Makassar city can reflect and have to think about how elements of urban design can certainly provide many benefits to the area and the surrounding environment, therefore it is very necessary to have a planning process and redesign of the Paotere fish landing station area in Makassar city to support the fishing industry in East of Indonesia.

\section{REFERENCES}

Asiyanto. (2008) Port Building Construction Methods. Jakarta: UI-Press.

Aulia, F. (2011). Service Conditions and Port Facilities Needs Related to Handling of Catches at Muara Angke Fish Landing Base. [Undergraduate Thesis]. Bogor: Bogor Agricultural Institute.

Bambang, T. (2010). Port Planning. Yogyakarta: Beta offset.

Danial. (2011). Fishery Port-Based Industry Development Model in Makassar City, South Sulawesi. http://respository.ipb.ac.id/handle/123456789/46638 (accessed on April 20, 2019).

Dyah P, Sulistyani. (2005). Analysis of the Efficiency of Class 1,2 and 3 TPI (Fish Auction Place) in Central Java and Its Development for Improving Fishermen's Welfare. Semarang: Diponegoro University.

Google earth (accessed: July 19, 2019 and August 19, 2019).

https://alficrot.wordpress.com/2013/11/05/perwisata-ke-kep-seribu/ (Accessed: July 20, 2019).

https://id.wikipedia.org/wiki/Kota_Makassar (Accessed: July 13, 2019).

https://id.wikipedia.org/wiki/Paotere (Accessed: July 13, 2019).

https://kbbi.web.id/ (Accessed: July 13, 2019).

https://pipp.djpt.kkp.go.id/profil_pelabuhan/1972/f Facilities_pokok (Accessed: July 20, 2019).

https://www.kompasiana.com/zahari/5510e376a33311ca39ba8e56/cold-storagedikuasaicukong (Accessed: July 20, 2019).

Mulyana, R. (2011). Relationship between Landing and Auction Activities on Facility Needs and Quality Conditions of Catches of Traditional Fleets at Pps Nizam Zachman Jakarta. Bogor: Bogor Agricultural University.

Mulyono, A. (2002). The Role of Fish Landing Base (PPI) Bajomulyo in Supporting Regional Autonomy in Pati Regency. [Doctoral Dissertation]. Semarang: Diponegoro University.

Mulyono, A. (2018) Redesign of the Fish Auction Place in Tegal City with an Ecological Architecture Approach. [Doctoral Dissertation]. Semarang: Sebelas Maret University.

Muninggar, R. (2001). Study on the Layout of Muara Angke Fish Landing Base Facilities (PPI) Jakarta. [Undergraduate Thesis]. Bogor: Bogor Agricultural Institute. 
Regulation of the Minister of Marine Affairs and Fisheries of the Republic of Indonesia, 2012.

Roosita, H. (2007). Guidelines for Amdal Assessment, or UKL/UPL for Port Development Activities, Assistant Deputy for Environmental Impact Assessment Deputy Minister for Environmental Management, State Ministry of Environment, Jakarta.

Shirvani, H. (1985). The Urban Design Process. New York: Van Nostrand Reinhold Company.

Sosilawati. (2017). Synchronization of the 2018-2020 Short-Term Development Program and Financing Integration of Regional Development with Sulawesi Island PUPR Infrastructure. Volume 1. Programming and Evaluation Center for PUPR Infrastructure Integration, Regional Infrastructure Development Agency, Ministry of Public Works, and Public Housing. Available at: http://books.google.co.id/books (Accessed: April 20, 2019).

Suyanto, T. (2006). An Analysis of Satisfaction Levels of Bidders and Perceived Quality Fish Auction Sites (TPI) at the Fish Landing Base (PPI) Muara Angke Jakarta. [Undergraduate Thesis]. Bogor: Bogor Agricultural Institute.

UPTD (Regional Technical Implementation Unit) Office of Makassar Paotere Fish Landing Base www.djpt.kkp.go.id (Accessed: July 14, 2019).

www.google.co.id (Accessed: November 9, 2019).

www.rmoljakarta.com (Accessed: July 20, 2019). 